\title{
The Role of Insulin in Norepinephrine Turnover and Thermogenesis in Brown Adipose Tissue after Acute Cold-Exposure
}

\author{
KeIJi YOSHIOKA, Toshinide YOSHIDA, Yasuo WAKABAYASHI*, \\ Hitoshi NISHIOKA AND MOTOHARU KONDO
}

\author{
First Department of Internal Medicine and Biochemistry*, \\ Kyoto Prefectural University of Medicine, \\ Kamikyo-ku, Kyoto 602, Japan
}

\begin{abstract}
The role of insulin in norepinephrine turnover (NE) and thermogenesis in brown adipose tissue (BAT) after acute cold-exposure was studied using streptozocin (STZ)-induced diabetic rats. NE turnover was estimated by the NE synthesis inhibition technique with $\alpha$-methyl-p-tyrosine. BAT thermogenesis was estimated by measuring mitochondrial guanosine-5'-diphosphate (GDP), cytochrome oxidase activity and mitochondrial oxygen consumption in BAT at an ambient temperature of $22^{\circ} \mathrm{C}$ and during a six-hour cold-exposure at $4^{\circ} \mathrm{C}$. In insulin-deficient diabetic rats, the NE turnover, mitochondrial GDP binding, cytochrome oxidase activity and mitochondrial oxygen consumption in BAT at $22^{\circ} \mathrm{C}$ were significantly reduced, compared with those of control rats. Treatment of STZ-induced diabetic rats with insulin prevented a decrease in $\mathrm{NE}$ turnover and BAT thermogenesis. Acute cold-exposure increased the NE turnover of BAT in insulin-deficient diabetic rats. The BAT thermogenic response to acute cold-exposure, however, did not occur in insulin-deficient diabetic rats. These results suggest that insulin is not essential in potentiating $\mathrm{NE}$ turnover in BAT after acute cold-exposure, but is required for cold-induced thermogenesis.
\end{abstract}

Brown adipose tissue (BAT) is now recognized as being a main effector of cold-induced thermogenesis (Foster and Frydman, 1979) and diet-induced thermogenesis (Rothwell and Stock, 1979).

\section{Received January 23, 1989}

Address all correspondence to KEIJI YOSHIOKA, First Department of Internal Medicine, Kyoto Prefectural University of Medicine, Kamikyo-ku, Kyoto 602, Japan
Thermogenesis in BAT is regulated primarily by the sympathetic nervous system (SNS) (Landsberg and Young, 1984; Giarardier and Seydoux, 1986).

Insulin-deficient diabetes is known to impair thermogenesis in response to diet (Rothwell and Stock, 1981). The decreased BAT thermogenesis in diabetic animals could be partly attributed to the reduced SNS activity in BAT (Yoshida et al., 1985, 1987). It may also be due to a defect 
in mitochondrial $\beta$-oxidation and changes in abundance (Seydoux et al., 1982, 1984) or guanosine- $5^{\prime}$-diphosphate (GDP) binding properties (Jamal and Saggerson, 1988) of uncoupling proteins in the BAT of diabetic animals.

Diabetic animals are also intolerant to cold-acclimation (Himms-Hagen, 1986). A recent report, however, has shown that a thermogenic response to acute coldexposure was activated in 2-day diabetic rats by measuring BAT temperature and cytochrome oxidase activity in the BAT (Shibata et al., 1987). Up to date, however, SNS activity or biochemical changes in the BAT mitochondria after acute coldexposure are less substantial in long-term insulin-deficient diabetic animals.

Therefore, the aim of this study is primarily to investigate whether SNS activity is increased by acute cold-exposure in an insulin-deficient state, by measuring norepinephrine (NE) turnover, and secondly to elucidate whether acute cold-induced thermogenesis occurs in an insulin-deficient state, by measuring GDP binding, cytochrome oxidase activity and oxygen consumption in the BAT mitochondria.

\section{Materials and Methods}

Two hundred and four female Sprague-Dawley rats (weighing, ca. $200 \mathrm{~g}, 8 \mathrm{w}$ ) were purchased from Charles River Japan (Osaka, Japan). One hundred and fifty rats were injected intravenously with streptozocin (STZ) (Upjohn, Kalamazoo, Michigan, USA) at a dose of $65 \mathrm{mg} / \mathrm{kg}$ freshly dissolved in ice-cold citrate buffer ( $\mathrm{pH} 4.5)$, and the other 54 rats with physiological saline (Control group). The animals were then housed in wire-mesh cages at a constant temperature of $22 \pm$ $2^{\circ} \mathrm{C}$ with artificial light from $0600 \mathrm{~h}$ to $1800 \mathrm{~h}$. They were allowed free access to commercial powdered chow (Charles River Japan) and tap water. The diabetic condition was verified by measuring plasma glucose levels with an autoanalyzer (Beckman, Fullerton, California, USA) 7 days after the injection of STZ. One hundred and forty-four diabetic animals having a plasma glucose level grater than $400 \mathrm{mg} / \mathrm{dl}$ were used in this experiment. One week after the induction of diabetes, 54 STZ-diabetic rats were treated with NPH insulin (Nordisk, Gentöfte, Denmark) at a dose of 4-8 U every evening $(1800 \mathrm{~h})$ [STZ (INS) group], and the other 90 STZ-diabetic rats were untreated [STZ (untreated) group]. Plasma glucose levels were measured at $1700 \mathrm{~h}$ once a week, and the dose of insulin was adjusted as followed: NPH insulin was given at a dose of $8 \mathrm{U}$ for plasma glucose levels $>$ $500 \mathrm{mg} / \mathrm{d} 1,6 \mathrm{U}$ for $500-400 \mathrm{mg} / \mathrm{dl}$, and $4 \mathrm{U}$ for $400-300 \mathrm{mg} / \mathrm{dl}$. Four weeks after STZ administration, the body weight, food intake and plasma glucose levels were measured. Two days after the measurement of these paramaters, the following experiments were carried out.

\section{Experiment 1 : Norepinephrine (NE) turnover}

Thirty rats each from the STZ(untreated), STZ(INS) and control groups were used in the experiment on NE turnover. NE turnover in interscapular BAT (IBAT) in each group was measured at an ambient temperature of $22^{\circ} \mathrm{C}$ and after a six-hour cold-exposure at $4^{\circ} \mathrm{C}$. The experiment started at $0900 \mathrm{~h}$. After the intraperitoneal injection of the methyl ester of $\alpha$ methyl-p-tyrosine $(80 \mathrm{mg} / \mathrm{kg}$, Sigma, St. Louis, MO, USA) dissolved in saline, 12 rats each in the STZ(untreated), STZ(INS) and control groups were placed in a cold room $\left(4^{\circ} \mathrm{C}\right)$, and 12 rats each in the STZ(untreated), STZ(INS) and control groups were kept at an ambient temperature of $22^{\circ} \mathrm{C}$. Six rats each in the STZ(untreated), STZ(INS) and control groups were not injected and served as the $0 \mathrm{~h}$ reference. Half of the 24 animals in each group were killed at $3 \mathrm{~h}$ and the other half killed at $6 \mathrm{~h}$. IBAT was rapidly removed, dissected from the connective tissue, weighed, homogenized in icecold $0.1 \mathrm{~N}$ perchloric acid containing $0.1 \mathrm{mM}$ reduced glutathione in a polytron (Kinematica, Lucerne, Switzerland) and centrifuged at $0^{\circ} \mathrm{C}$. Aliquots of the supernatant were stored at $-70^{\circ} \mathrm{C}$ for later determination of NE (usually within 1 week). NE was assayed radioenzymatically with a minor modification (Yoshida et al., 1983) of the method of Peuler and Johnson (1977). All data are presented as the mean \pm S.E. Statistical analysis was performed by the analysis of variance and covariance (Zar, 1974). Comparisons of fractional turnover rates were 
calculated as the product of the fractional turnover rate $(\mathrm{k})$ times the endogenous NE concentration at point zero. $95 \%$ confidence intervals were determined for the NE turnover rates as described previously (Taubin et al., 1979).

\section{Experiment 2: Brown adipose tissue thermo- genesis}

Twenty-four rats each in the STZ(INS) and control groups, and 60 rats in the STZ(untreated) group were used in the experiment on BAT thermogenesis. Mitochondrial GDP binding, cytochrome oxidase activity and oxygen consumption in the IBAT of each group were measured at $22^{\circ} \mathrm{C}$ and a six hour cold-exposure at $4^{\circ} \mathrm{C}$. The rats were killed by cervical dislocation at $0900 \mathrm{~h}$. Interscapular BAT was rapidly removed and dissected from the connective tissue. For one measurement of the parameters described below, interscapular BAT samples were collected from 3 rats in the control and STZ(INS) groups, and 6 rats in the STZ(untreated) groups at $22^{\circ} \mathrm{C}$, and from one rat in the control and STZ(INS) groups, and 4 rats in the STZ(untreated) group at $4^{\circ} \mathrm{C}$. BAT samples were weighed and homogenized in an ice-cold medium ( $\mathrm{pH}$ 7.2) containing $250 \mathrm{mM}$ sucrose and $5 \mathrm{mM}$ TES. Portions of the homogenates were used for the measurement of cytochrome oxidase activity. The mitochondria were isolated by differential centrifugation according to the procedure described by Cannon and Lindberg (1973). The tissue protein and mitochondrial protein were estimated by the method of Lowry et al. (1951). Mitochondrial GDP binding was determined by incubation and filtration according to a minor modification (Yoshioka et al., 1988) of the method of Nicholls (1976). The mitochondria were incubated at $20^{\circ} \mathrm{C}$ in $0.5 \mathrm{ml}$ of medium containing $\left[{ }^{3} \mathrm{H}\right]$-GDP $(1.30 \mu \mathrm{Ci}),\left[{ }^{14} \mathrm{C}\right]-$ sucrose $(0.123 \mu \mathrm{Ci}), 100 \mu \mathrm{M}$ sucrose, $100 \mu \mathrm{M}$ potassium atractyloside, $20 \mathrm{mM}$ TES (pH 7.1), $10 \mathrm{mM}$ choline chloride and $5 \mu \mathrm{M}$ rotenone. After 7 minutes of incubation, $0.4 \mathrm{ml}$ aliquots containing $0.26 \mathrm{mg}$ of mitochondrial protein were withdrawn and filtered through a nitrocellulose membrane filter(Sartorius, Göttingen, W. Germany, pore size $0.45 \mu \mathrm{m})$. The filters were counted for $\left[{ }^{3} \mathrm{H}\right]$ and $\left[{ }^{14} \mathrm{C}\right]$ in a scintillation counter (Packard, Downers, Grove, IL, USA). Cytochrome oxidase activity was measured spectrophotometrically with a Double-Beam Spectrophotometer (UV-140-02, Shimadzu, Kyoto) at $25^{\circ} \mathrm{C}$ in $1 \mathrm{ml}$ of a medium consisting of $100 \mathrm{mM} \mathrm{KH}_{2} \mathrm{PO}_{4}, 1 \mathrm{mM}$ EDTA and $30 \mu \mathrm{M}$ reduced cytochrome $\mathrm{c}$ after treating the homogenates with $1 \%$ Lubrol by the method of Yonetani and Ray (1965). Mitochondrial respiration was determined polarographically in $2 \mathrm{ml}$ of medium consisting of $100 \mathrm{mM} \mathrm{KCl}, 20 \mathrm{mM}$ TES (pH 7.2), $4 \mathrm{mM} \mathrm{KH}_{2} \mathrm{PO}_{4}, 2 \mathrm{mM} \mathrm{MgCl}_{2}$, $1 \mathrm{mM}$ EDTA, $4 \mu \mathrm{M}$ rotenone and $10 \%$ defatted BSA at $25^{\circ} \mathrm{C}$ with Rank oxygen equipment (Rank Brotteus, Cambridge, UK). Mitochondrial protein $(850 \mu \mathrm{g})$ was added to a medium and $10 \mathrm{mM}$ $\alpha$-glycerophosphate was added as a substrate for mitochondrial respiration. All data are presented as the mean \pm S.E. Statistical analysis was done by Student's $t$-test.

Table 1. Body weight, food intake, plasma glucose level and pancreatic insulin content in control, STZ(untreated) and STZ(INS) rats at an ambient temperature of $22^{\circ} \mathrm{C}$.

\begin{tabular}{|c|c|c|c|}
\hline & Control & STZ(untreated) & STZ(INS) \\
\hline $\mathrm{n}$ & 18 & 36 & 18 \\
\hline Body weight & $258.3 \pm 5.5$ & $189.3 \pm 6.2^{b}$ & $245.2 \pm 6.0^{\mathrm{e}}$ \\
\hline Food intake & $24.0 \pm 11.4$ & $45.7 \pm 5.8^{\mathrm{a}}$ & $31.1 \pm 5.2$ \\
\hline Plasma glucose level (mg/dl) & $89.9 \pm 4.4$ & $462.2 \pm 17.2^{\mathrm{b}}$ & $186.2 \pm 17.9^{\mathrm{c}, \mathrm{e}}$ \\
\hline $\begin{array}{l}\text { Pancreatic insulin content } \\
(\mathrm{mU} / \mathrm{g} \cdot \text { pancreas })\end{array}$ & $1018.0 \pm 52.6$ & $24.1 \pm 10.9^{\mathrm{b}}$ & $25.2 \pm 13.4^{\mathrm{d}}$ \\
\hline
\end{tabular}

Values are shown as the mean \pm S.E. $n:$ Number of animals in each group

Control vs STZ(untreated) : a ; p $<0.05$

$\mathrm{b} ; \mathrm{p}<0.001$

Control vs STZ(INS) $\quad: \mathrm{c} ; \mathrm{p}<0.02$

$\mathrm{d} ; \mathrm{p}<0.001$

STZ(untreated) vs STZ(INS) : e ; p $<0.001$ 


\section{Results}

Table 1 shows body weight, food intake, plasma glucose level and pancreatic insulin content of the control, untreated STZ [STZ (untreated)] and STZ treated with insulin [STZ(INS)] groups 4 weeks after the STZ administration. The STZ(untreated) group was significantly lighter in body weight than the control or STZ(INS) groups $(\mathrm{p}<$ $0.001)$. Food intake was significantly greater in the $S T Z$ (untreated) group than in the control group $(p<0.05)$. However, daily insulin injections given to STZ rats decreased food intake to levels equal to the control. Plasma glucose levels in the STZ (untreated) group were markedly higher than those in the control or STZ(INS) groups $(\mathrm{p}<0.001)$. Pancreatic insulin content was significantly lower in the STZ (untreated) and STZ(INS) groups than in the control group $(\mathrm{p}<0.001)$.

Experiment 1: Table 2 and Figure 1 show the NE turnover data for IBAT of the control, STZ(untreated) and STZ(INS)
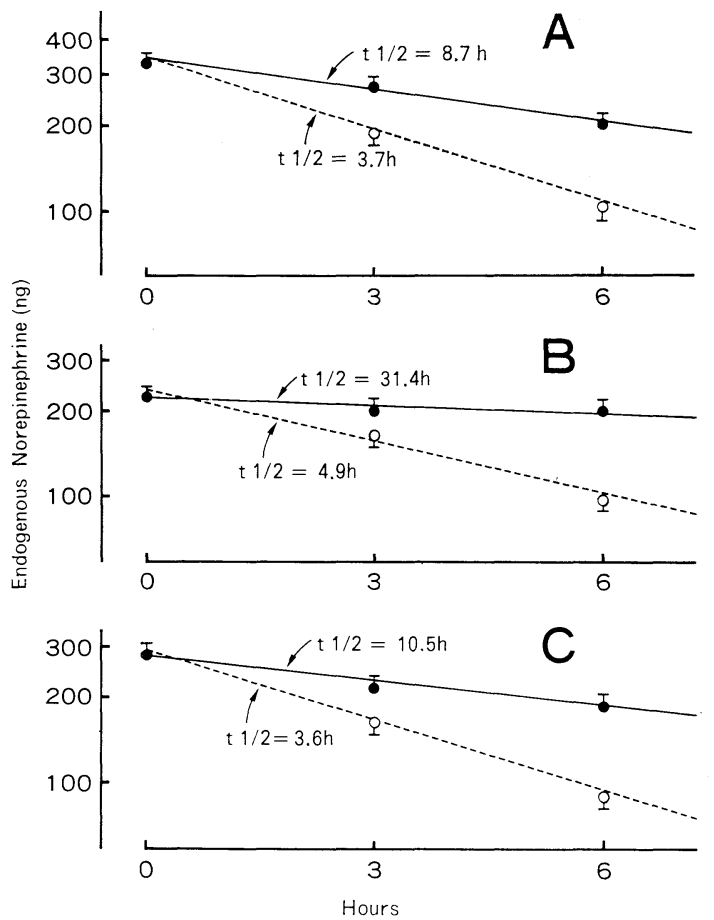

Fig. 1. Effect of ambient temperature $\left(22^{\circ} \mathrm{C}\right)$ (-O) and acute cold-exposure $\left(4^{\circ} \mathrm{C}\right)\left(\mathrm{O}^{-\cdots} \bigcirc\right)$ on the norepinephrine turnover in the interscapular brown adipose tissue of the Control (A), STZ(untreated)(B) and STZ(INS)(C) rats.

Table 2. Effect of ambient temperature $\left(22^{\circ} \mathrm{C}\right)$ and acute cold-exposure $\left(4^{\circ} \mathrm{C}\right)$ on norepinephrine turnover in the interscapular brown adipose tissue of control, STZ(untreated) and STZ(INS) rats.

\begin{tabular}{|c|c|c|c|c|}
\hline & \multirow{2}{*}{$\begin{array}{c}\text { Ambient } \\
\text { temperature } \\
\left({ }^{\circ} \mathrm{C}\right)\end{array}$} & \multicolumn{3}{|c|}{ IBAT } \\
\hline & & $\begin{array}{c}\text { endogenous NE } \\
\text { (ng/organ) }\end{array}$ & $\begin{array}{c}\mathrm{k} \\
(\% / \mathrm{h}) \\
\end{array}$ & $\begin{array}{c}\mathrm{NE} \cdot \mathrm{Tr} \\
(\mathrm{ng} / \text { organ} / \mathrm{h})\end{array}$ \\
\hline Control & $\begin{array}{r}22 \\
4\end{array}$ & $330.2 \pm 13.5$ & $\begin{array}{c}7.9 \pm 1.1 \\
18.7 \pm 1.8^{\mathrm{a}}\end{array}$ & $\begin{array}{l}26.1 \pm 4.8 \\
61.7 \pm 8.8\end{array}$ \\
\hline STZ (untreated) & $\begin{array}{r}22 \\
4\end{array}$ & $225.5 \pm 11.2^{\mathrm{c}}$ & $\begin{array}{r}2.2 \pm 1.0^{\mathrm{b}} \\
14.1 \pm 1.5^{\mathrm{a}}\end{array}$ & $\begin{array}{r}5.0 \pm 2.6 \\
31.8 \pm 5.1\end{array}$ \\
\hline STZ (INS) & $\begin{array}{r}22 \\
4 \\
\end{array}$ & $280.5 \pm 8.3^{\mathrm{d}, \mathrm{e}}$ & $\begin{array}{c}6.6 \pm 1.3 \\
19.3 \pm 1.6^{\mathrm{a}}\end{array}$ & $\begin{array}{l}14.9 \pm 4.0 \\
54.1 \pm 6.3 \\
\end{array}$ \\
\hline
\end{tabular}

The fractional NE turnover rate $(\mathrm{k})$ is expressed as the mean \pm S.E.

The NE turnover (NE·Tr) is expressed as the mean with $95 \%$ confidence limits.

Six rats were used at each time point to obtain the turnover data.

$22^{\circ} \mathrm{C}$ vs $4^{\circ} \mathrm{C}: \mathrm{a} ; \mathrm{p}<0.01$

$$
\begin{array}{ll}
\text { Control }\left(22^{\circ} \mathrm{C}\right) \text { vs } \mathrm{STZ} \text { (untreated) }\left(22^{\circ} \mathrm{C}\right) & : \mathrm{b} ; \mathrm{p}<0.02 \\
& \mathrm{c} ; \mathrm{p}<0.001 \\
\text { Control }\left(22^{\circ} \mathrm{C}\right) \text { vs } \mathrm{STZ}(\mathrm{INS})\left(22^{\circ} \mathrm{C}\right) & \mathrm{d} ; \mathrm{p}<0.02 \\
\text { STZ(untreated) }\left(22^{\circ} \mathrm{C}\right) \text { vs STZ(INS) }\left(22^{\circ} \mathrm{C}\right): \text { : } ; \mathrm{p}<0.02
\end{array}
$$


Vol. 36, No. 4 INSULIN, BAT-SNS \& TERMOGENESTS IN COLD

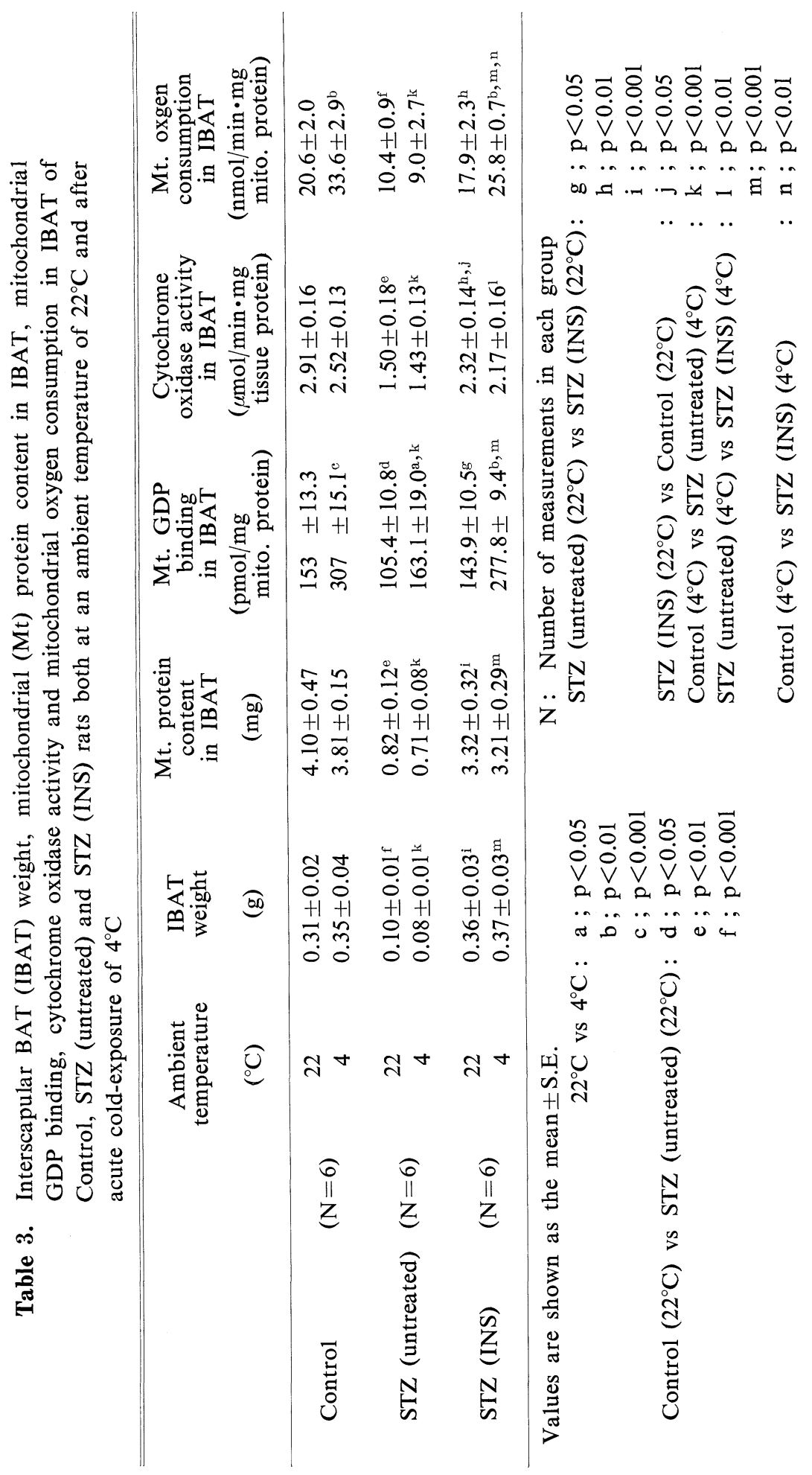


groups at an ambient temperature of $22^{\circ} \mathrm{C}$ and after acute cold-exposure at $4^{\circ} \mathrm{C}$. Endogenous NE levels in the IBATs of the STZ(untreated) group were less than those of the control group at an ambient temperature of $22^{\circ} \mathrm{C}(\mathrm{p}<0.001)$. The fractional $\mathrm{NE}$ turnover rate $(\mathrm{k})$ and the total $\mathrm{NE}$ turnover rate in the IBAT of the STZ(untreated) group at $22^{\circ} \mathrm{C}$ were significantly slower than in the control group. Treatment of the STZ rats with insulin prevented a decrease in the fractional and total NE turnover rates in the IBAT. When STZ(untreated) rats were exposed to cold at $4^{\circ} \mathrm{C}$ for 6 hours, the $\mathrm{NE}$ turnover rate in the IBAT significantly increased as compared with $S T Z$ (untreated) rats maintained at $22^{\circ} \mathrm{C}$. This phenomenon was also observed in the control and STZ(INS) groups.

Experiment 2: Table 3 shows IBAT weight, the mitochondrial protein content in IBAT, mitochondrial GDP binding, cytochrome oxidase activity and mitochondrial oxygen consumption in IBAT of the control, STZ(untreated) and STZ(INS) groups at an ambient temperature of $22^{\circ} \mathrm{C}$ and also at $4^{\circ} \mathrm{C}$. The IBAT weight and mitochondrial protein content in IBAT of the STZ(untreated) group were significantly decreased as compared with those in the control and STZ(INS) groups at both $22^{\circ} \mathrm{C}$ and $4^{\circ} \mathrm{C}$. Mitochondrial GDP binding, cytochrome oxidase activity and mitochondrial oxygen consumption in the IBAT of the STZ(untreated) group were significantly lower than those in the control group at an ambient temperature of $22^{\circ} \mathrm{C}(\mathrm{p}<0.05-0.001)$. A six-hour cold-exposure of the control and STZ(INS) rats at $4^{\circ} \mathrm{C}$ resulted in enhanced mitochondrial GDP binding and oxygen consumption in the IBAT as compared with those at the ambient temperature of $22^{\circ} \mathrm{C}(\mathrm{p}<0.01-0.001)$. In STZ(untreated) rats, mitochondrial GDP binding in the IBAT was increased by acute cold-exposure at $4^{\circ} \mathrm{C} \quad(\mathrm{p}<0.05)$. However, the mitochondrial oxygen consumption in the IBAT did not increase.

\section{Discussion}

The present study demonstrates that NE turnover and thermogenesis in BAT were decreased in insulin-deficient diabetic rats, and that acute cold-exposure could activate NE turnover in BAT but not BAT thermogenesis.

In STZ-induced diabetic rats, the NE turnover at an ambient temperature of $22^{\circ} \mathrm{C}$, which is a reliable indicator of SNS activity (Young and Landsberg, 1977; Vander Tuig et al., 1982; Yoshida and Bray, 1983), was markedly reduced as compared with that of the control rats. Treatment of STZinduced diabetic rats with insulin prevented the reduction of the NE turnover in BAT. The present data are completely in accordance with those obtained in our previous studies (Yoshida et al., 1985, 1987).

Acute cold-exposure at $4^{\circ} \mathrm{C}$ activated $\mathrm{NE}$ turnover in BATs not only in the control and STZ(INS) groups, but also in the STZ(untreated) group. These results suggest that insulin is not required for the activation of NE turnover after acute cold-exposure. It is suggested that the center of cold-induced thermogenesis is the preoptic area and spinal cord (Banet et al., 1978) and that of diet-induced thermogenesis is the ventromedial hypothalamus (VMH) (Bray and York, 1979; Yoshida and Bray, 1984). Signals to the SNS from the environmental temperature and diet would be processed separately in the hypothalamus. Therefore, insulin might not be essential for the activation of NE turnover after acute cold-exposure.

It is known that a proton conductance pathway, losely coupled with respiration across the BAT mitochondrial inner membrane, generates BAT thermogenesis (Trayhurn, et al., 1986). The pathway is regulated by a mitochondrial inner membrane protein 
'uncoupling protein', which has a high affinity for purine nucleotide. Here GDP is useful in detecting the presence of uncoupling protein (Nicholls, 1976).

The levels of GDP binding, cytochrome oxidase activity and oxygen consumption in BAT mitochondria at $22^{\circ} \mathrm{C}$ were significantly decreased in the STZ-induced diabetic rats. Treating the STZ-induced diabetic rats with insulin restored these parameters. The present results are in accordance with other reports (Seydoux et al., 1984; Jamal and Saggerson, 1988), in which a decrease in the mitochondrial abundance or reduced GDP binding in BAT contributes to the reduced BAT thermogenesis in insulin-deficient diabetic rats.

The defect in the BAT thermogenesis of insulin-deficient diabetic animals has also been attributed to a marked reduction of the $\beta$-oxidation capacity of free fatty acids (Seydoux et al., 1984) as well as to a decreased ability to synthesize or accumulate fatty acids for fuel in BAT thermogenesis (Trayhurn, 1981). Furthermore, STZ-induced diabetic rats may be in the hypothyroid state which may also contribute to the impairment of BAT thermogenesis (OrtizCaro et al., 1984; Bestetti et al. 1987).

With the activation of NE turnover, acute cold-exposure increased GDP binding in insulin-deficient diabetic rats as well as control rats. Mitochondrial oxygen consumption, however, could not be increased by acute cold-exposure in insulin-deficient diabetic rats. In contract, acute coldexposure increased mitochondrial oxygen consumption in the BAT in the control and STZ(INS) groups. The discrepancy between GDP binding and oxygen comsumption in BAT mitochondria in insulin-deficient diabetic rats may be due to the 'unmasking' of GDP binding sites of uncoupling protein (Swick and Swick, 1986; Gribskov et al., 1986).

A recent report, however, has shown that acute cold-exposure increases heat production of IBAT in 2-day diabetic rats (Shibata, 1987). In 2-day diabetic rats, tissue protein or cytochrome oxidase activity in BAT were decreased only at $70 \%$ of the level of those in the control rats. It is likely that cold-induced thermogenic capacity may be still preserved in 2-day diabetic rats. In our long-term diabetic rats, however, the levels of these parameters markedly decreased to below about the $40 \%$ level of those in the control rats. This may have contributed to the impairment of acute cold-induced thermogenesis.

The work of others has demonstrated a marked increase in the sensitivity to insulin induced by cold-exposure (Vallerand et al., 1986, 1987; Bartness et al., 1986a, 1986b). Cold-exposure potentiates the effect of insulin on in vivo glucose uptake in BAT at a normal insulin level, and glucose would principally be utilized in de novo lipogenesis as fuel for BAT thermogenesis. In insulin-deficient diabetic rats, however, the uptake of glucose in BAT would be impaired even in cold-exposure.

In conclusion, the present study demonstrates that insulin is not essential in potentiating NE turnover in BAT after acute cold-exposure, but is required for cold-induced thermogenesis.

\section{Acknowledgement}

We thank Ms. Miyazaki and Ms. Nomura for their technical help. This research was supported in part by grants-in-aid (61570567 and 63570552) for scientific research from the Ministry of Education, Science and Culture of Japan, and grants from Mitsui Life Social Welfare Foundation, Meiji Life Social Welfare Foundation and the Smoking Research Foundation.

\section{References}

Banet, M., H. Hensel and H. Liebenmann (1978). Central control of shivering and non-shivering 
thermogenesis in the rat. J. Physiol. 283, 569584.

Bartness, T. J., C. J. Billington, A. S. Levine, J. E. Morley, D. M. Brown and N. E. Rowland (1986a). Insulin and metabolic efficiency in rats. I. Effects of sucrose feeding and BAT axotomy. Am. J. Physiol. 251, R1109-R1117.

Bartness, T. J., C. J. Billington, A. S. Levine, J. E. Morley, D. M. Brown and N. E. Rowland (1986b). Insulin and metabolic efficiency in rats. II. Effect of $\mathrm{NE}$ and cold exposure. Am. J. Physiol. 251, R1118-R1125.

Bestetti, T. J., M. J. Reymond, I. V. Perrin, P. C. Knie1, T. LeMarchand-Beraud and G. L. Rossi (1987). Thyroid and pituitary-secretory disorders in streptozotocin-diabetic rats are associated with severe structural changes in these glands. Virchows Arch. B. 53, 69-78.

Bray, G. A. and D. A. York (1979). Hypothalamic and genetic obesity in experimental animals: An autonomic and endocrine hypothesis. Physiol. Rev. 59, 719-809.

Cannon, B. and O. Lindberg (1979). Mitochondria from brown adipose tissue: Isolation and properties. Method Enzymol. 55, 65-78.

Foster, D. O. and M. L. Frydman (1979). Tissue distribution of cold-induced thermogenesis in conscious warm- or cold-acclimated rats reevaluated from changes in tissue blood flow: The dominant role of brown adipose tissue in the replacement of shivering by nonshivering thermogenesis. Can. I. Physiol. Pharmacol. 57, 257-270.

Girardier, L. and J. Seydoux (1986). Neural control of brown adipose tissue: In : Brown adipose tissue (P. Trayhurn and D. G. Nicholls eds.), Edward, London, pp 122-151.

Gribskov, C. L., M. F. Henningfield, A. G. Swick and R. W. Swick (1986). Evidence for unmasking of rat brown-adipose-tissue mitochondrial GDP-binding sites in response to acute cold exposure: Effect of washing with albumin on GDP binding. Biochem. J. 233, 743-747.

Himms-Hagen, L. (1986). Brown adipose tissue and cold-acclimation: In : Brown adipose tissue (P. Trayhurn and D. G. Nicholls eds.). Edward Arnold, London, pp 214-268.

Jama1, Z. and E. D. Saggerson (1988). Factors influencing the altered thermogenic response of rat brown adipose tissue in streptozotocindiabetes. Biochem. J. 249, 415-421.

Landsberg, L. and J. B. Young (1984). The role of the sympathoadrenal system in modulating energy expenditure. Clin. Endocrinol. Metab. 13, 475-499.

Lowry, O. H., J. Rosenbrough, A. L. Farr and R. L. Randa1l (1951). Protein measurement with Folin phenol reagent. J. Biol. Chem. 193, 265-275.

Nicholls, D. G. (1976). Hamster brown adipose tissue mitochondria: purine nucleotide control of ion conductance of the inner membrane and the nature of the nucleotide binding site. Eur. J. Biochem. 62, 223-228.

Ortiz-Caro, J. C., C. Gonzalex and T. Jolin (1984). Dural variations of plasma growth hormone, thyrotropin, thyroxine and triiodothyronine in streptozocin-diabtic and foodrestricted rats. Endocrinology 115, 2227-2232.

Peuler, J. D. and G. A. Johnson (1977). Simultaneous single isotope radioenzymatic assay of plasma norepinephrine, epinephrine and dopamine. Life Sci. 21, 625-636.

Rothwell, N. J. and M. J. Stock (1979). A role for brown adipose tissue in diet-induced thermogenesis. Nature 281, 31-35.

Rothwell, N. J. and M. J. Stock (1981). A role for insulin in the diet-induced thermogenesis of cafeteria-fed rats. Metabolism 30, 673-678.

Seydoux, J., A. Chinet, G. Schneider-Pichard, S. Bas, E. Imesh, F. Assimacopoulos-Jeannet, J. P. Giacobino and L. Giradier (1983). Brown adipose tissue metabolism in streptozotocindiabetic rats. Endocrinology 113, 604-610.

Seydoux, J., E. R. Trimble, F. Bouillaud, F. Assimacopoulos-Jeannet, S. Bas, D. Ricquire, J. P. Giacobino and L. Girardier (1984). Modulation of $\beta$-oxidation and proton conductance pathway of brown adipose tissue in hypo- and hyperinsulinemic states. FEBS Lett. 166, 141-145.

Shibata, H., F. Pérusse and L. J. Bukowiecki (1987). The role of insulin for nonshivering thermogenesis. Can. J. Physiol. Pharmacol. 65, 152-158.

Swick, A. G. and R. W. Swick (1986). Rapid changes in number of GDP binding sites on brown adipose tissue mitochondria. Am. $J$. Physiol. 251, E192-E195.

Taubin, H. L., B. Djahanguri and L. Landsberg (1972). Noradrenalin concentration and turnover in different regions of the gastrointestinal tract of the rat: an approach to the evaluation of sympathetic activity in the gut. Gut 13, 65-78. 
Trayhurn, P. (1981). Fatty acid synthesis in mouse brown adipose tissue: The influence of environmental temperature on the proportion of whole-body fatty acid synthesis in brown adipose tissue and liver. Biochem. Biophys. Acta 664, 549-560.

Trayhurn, P., M. Ashwell, G. Jennings, D. Richard and D. M. String (1986). Effect of warm or cold exposure on GDP binding and uncoupling protein in rat brown fat. Am. J. Physiol. 252, E237-E243.

Yonetani, T. and G. S. Ray (1965). Studies on Cytochrome oxidase: Kinetics of the aerobic oxidation of ferrocytochrome $\mathrm{c}$ by cytochrome oxidase. J. Biol. Chem. 240, 3392-3398.

Yoshida, T., J. W. Kemnitz and G. A. Bray (1983). Latera1 hypothalamic lesions and norepinephrine turnover in rats. J. Clin. Invest. 72, 919-927.

Yoshida, T. and G. A. Bray (1984). Catecholamine turnover in rats with ventromedial hypothalamic lesions. Am. J. Physiol. 246, R558R565.

Yoshida, T., H. Nishioka, Y. Nakamura and M. Kondo (1985). Reduced noradrenalin turnover in streptozotocin-induced diabetic rats. Diabetologia 28, 692-696.

Yoshida, T., H. Nishioka, K. Yoshioka, K.
Nakano, M. Kondo and H. Terashima (1987). Effect of aldose reductase inhibitor ONO 2235 on reduced sympathetic nervous system activity and peripheral nerve disorders in STZinduced diabetic rats. Diabetes 36, 6-13.

Yoshioka, K., T. Yoshida, Y. Wakabayashi, H. Nishioka and M. Kondo (1988). Reduced brown adipose tissue thermogenesis of obese rats after ovariectomy. Endocrinol. Japon. 35, 537-543.

Young, J. B. and L. Landsberg (1977). Stimulation of the sympathetic nervous system during sucrose feeding. Nature 269, 615-617.

Vallerand, A. L., J. Lupien and L. J. Bukowiecki (1986). Cold exposure reverses the diabetogenic effects of high-fat feeding. Diabetes 35, 329334.

Vallerand, A. L., F. Pérusse and L. J. Bukowiecki (1987). Cold exposure potentiates the effect of insulin on in vivo glucose uptake. Am. J. Physiol. 253, E179-E186.

Vander Tuig, J. G., A. W. Knehans and D. R. Romsos (1982). Reduced sympathetic nervous system activity in rats with ventromedial hypothalamic lesions Life Sci. 30, 913-920.

Zar, J. H. (1974). Biostatistical Analysis. Prentice-Ha11, Englewood, Cliffs, N. J. pp 41-235. 